\title{
DYNAMICS OF DAIRY PRODUCTS CONSUMPTION IN POLAND AGAINST THE BACKGROUND OF THE EU
}

\author{
Piotr Bórawski ${ }^{1 凶}$, Mariola Grzybowska-Brzezińska ${ }^{1}$, James W. Dunn² \\ ${ }^{1}$ University of Warmia and Mazury in Olsztyn, Poland \\ ${ }^{2}$ Pennsylvania State University, USA
}

\begin{abstract}
Consumption is among the key determinants of milk production and profitability. The main purpose of this paper is to present the level of and changes in milk and dairy products consumption in the EU in 2004-2018. Due to changing consumer preferences, the average consumption of milk and milk products in EU countries is on an increase. In turn, Poland witnesses growth in consumption of milk for ripening and processed cheese and yogurt. In 2004-2017, per capita consumption of ice cream, cheese and powdered milk followed a downward trend. In order to examine changes in the consumption of milk and milk products, a forecast was prepared which shows that in 2018-2022, Poland will experience an increase in the average monthly consumption of milk, ice cream and cheese. On the other hand, the EU will report growth in consumption of fresh dairy products, butter, cheese, skim milk and powdered milk, and a decrease in casein consumption.
\end{abstract}

Keywords: consumption, milk, EU countries, Poland

\section{INTRODUCTION}

The global milk market is undergoing changes related to production, consumption, prices and other factors. Generally, EU countries recorded an increase in the consumption of processed dairy products such as butter, cheese, skim milk powder and whole milk powder in 2004-2018. However, the consumption of fresh dairy products and casein decreased (Rynek mleka..., 2016).
The main EU milk producers are Germany, France, UK, the Netherlands and Poland. Germany continues to be the most important milk producer and consumer, where milk consumption in kilograms per capita increased from 292 to 364 in 2005-2017 (Dairy report, 2018). In the major milk producing regions, farmers make investments that help them increase production while also improving competitiveness in the marketplace (Guth, 2017).

Among the EU-13 countries, Poland remains an important producer and a major consumer of milk. Between 2000 and 2016, Poland saw improvements in the milk consumption balance, including as regards milk intended for dairy products (except for milk processed into butter), and enhancements in the integration and logistics of the dairy industry. This increased the importance of supply chains which enable greater cooperation between dairy companies, suppliers and customers (Bórawski, 2016).

Generally, underdeveloped, developing and developed countries all saw an increase in milk consumption. This is due to the growing awareness of the role of milk as an essential ingredient in human diet. The increase in milk consumption is mainly driven by world population growth. Milk consumption increased almost four times in China between 2000 and 2013 (Kołoszyc, 2016).

There are many factors that increase milk consumption, primarily including the increase in population and in consumption per capita. Currently, population is

\footnotetext{
Piotr Bórawski, Department of Agrotechnology, Agricultural Production Management and Agribusiness, University of Warmia and Mazury in Olsztyn, M. Oczapowskiego 8 St., 10-719 Olsztyn, Poland, e-mail: pboraw@uwm.edu.pl, https://orcid. org/0000-0002-6616-7140
}

(C) Copyright by Wydawnictwo Uniwersytetu Przyrodniczego w Poznaniu 
observed to grow at an annual rate of $1.2-1.3 \%$ which causes consumption to increase by $7-9$ million tons per year (Sahdev, 2015). The second factor is the increase in incomes per capita which leads to an increased consumption of dairy products (FAO, 2013).

Moreover, the dairy industry is growing rapidly in China, and milk consumption has become more common in urban areas (Wiley and Madison, 2007). A significant increase has been observed in India, too. "Meanwhile, in the United States, consumption has declined markedly, especially among children" (Wiley, 2011).

The consequence of the increasing consumption of dairy products has contributed to the increase in milk production. According to the Food and Agriculture Organization of the United Nations (FAO), the total dairy production around the world was 805 million tons in 2015 (Ogunyale and Mayorga, 2017).

Milk is considered a healthy product for people, and should be included in human diet. "Milk is viewed as especially appropriate for children, with growth-promoting properties; the larger size and athletic success of western athletes is often attributed to their greater milk consumption" (Wiley and Madison, 2007).

\section{PURPOSE AND METHODOLOGY}

The main purpose of this research was to identify changes in the consumption of milk and dairy products in Poland compared to the EU. In addition to the main objective, the following specific objectives were also met:

1. Evaluating milk and dairy products consumption in Poland and the EU.

2. Assessing changes in the consumption of milk and dairy products in Poland and the EU.

3. Developing a forecast of milk and dairy products consumption.

4. Identifying the drivers of milk consumption in Poland.

This paper uses tabular and descriptive methods. In turn, deductive inference based on a mathematical analysis of historical data was used to determine the expected future changes for 2018-2020. The time series consisted of annual data for 2004-2017. The authors relied on Statistica 13 in preparing the forecast based on this data.

The following multiple regression equation was used to identify the factors affecting milk production in Poland (Sobczyk, 2005):

$$
y_{i}=\beta_{o}+\sum_{j=1}^{K} \beta_{j} X_{i j}+\varepsilon_{i}
$$

where:

$y_{i}: i^{\text {th }}-$ observation for the explanatory variable $(i=$ $1,2, \ldots, n)$

$X_{i j}: t^{\text {th }}$ - observation for the $j^{\text {th }}$ explanatory variable from the set of explanatory variables

$\beta_{o}, \beta_{j}-$ structural parameters of the regression equation

Milk consumption was described using a variable with variability characteristics shown in the following model (1):

$$
Y_{1}: \text { milk consumption per capita. }
$$

Substantive criteria and data availability were taken into account when selecting the model's explanatory variables as shown below:

$X_{1}$ - milk production (thousand liters)

$X_{2}-$ PLN/EUR exchange rate

$X_{3}-$ milk prices paid to farmers in Poland (EUR/100 kg)

$X_{4}$ - retail prices of milk with a $3-3.5 \%$ fat content (PLN/1 1)

$X_{5}-$ FAO global milk price index

$X_{6}-$ net trade in dairy products (EUR million)

$X_{7}$ - disposable income (PLN)

$X_{8}$ - average monthly expenses per capita (PLN)

$X_{9}$ - the share of expenses in disposable income (\%)

The authors used different sources of data. Historical data from the domestic dairy market was used to estimate the development trends in milk and dairy products consumption in Poland. Moreover, OECD data was used to describe the consumption of dairy products in EU countries between 2004 and 2017. EU country-level trends in butter and butteroil consumption between 2008 and 2017 were identified based on the analysis of milk market data.

\section{RESEARCH RESULTS}

The authors of this paper wanted to identify the factors affecting milk consumption. The first of them is milk production (Table 1) which increased from 11566 million liters in 2004 to 13305 million liters in 2017 (Bórawski, 2015). The EU is an important milk producer 
Bórawski, P., Grzybowska-Brzezińska, M., Dunn, J. W. (2020). Dynamics of dairy products consumption in Poland against the background of the EU. J. Agribus. Rural Dev., 2(56), 145-154. http://dx.doi.org/10.17306/J.JARD.2020.01296

Table 1. Market conditions for milk production in Poland in 2004-2017

\begin{tabular}{|c|c|c|c|c|c|c|c|c|c|c|c|c|c|c|}
\hline Specification & 2004 & 2005 & 2006 & 2007 & 2008 & 2009 & 2010 & 2011 & 2012 & 2013 & 2014 & 2015 & 2016 & 2017 \\
\hline $\begin{array}{l}\text { Milk production } \\
\text { (million liters) }\end{array}$ & 11566 & 11905 & 11974 & 12088 & 12418 & 12439 & 12270 & 12405 & 12659 & 12718 & 12986 & 13236 & 13244 & 13305 \\
\hline Exchange rate (PLN) & 4.6640 & 4.0373 & 3.8952 & 3.7829 & 3.5166 & 4.3273 & 3.9946 & 4.1198 & 4.1969 & 4.2033 & 4.1847 & 4.1848 & 4.3757 & 4.2260 \\
\hline $\begin{array}{l}\text { Milk prices paid to } \\
\text { farmers in Poland } \\
(E U R / 100 \mathrm{~kg})\end{array}$ & 23.8 & 24.9 & 25.4 & 29.6 & 30.3 & 22.2 & 27.3 & 29.5 & 28.8 & 31.8 & 32.3 & 27.8 & 26.0 & 32.3 \\
\hline $\begin{array}{l}\text { Retail prices of milk } \\
\text { with a } 3-3.5 \% \text { fat } \\
\text { content (PLN/liter) }\end{array}$ & 2.43 & 2.46 & 2.42 & 2.54 & 2.80 & 2.72 & 2.68 & 2.73 & 2.77 & 2.81 & 2.99 & 2.87 & 2.73 & 2.77 \\
\hline $\begin{array}{l}\text { FAO global milk } \\
\text { price index }\end{array}$ & 123.5 & 135.2 & 129.7 & 219.1 & 223.1 & 148.6 & 206.6 & 229.5 & 193.6 & 242.7 & 224.1 & 60.3 & 153.8 & 202.2 \\
\hline $\begin{array}{l}\text { Net trade in dairy } \\
\text { products (EUR } \\
\text { million) }\end{array}$ & 505 & 752.7 & 748 & 866.4 & 889 & 633 & 777.8 & 874.4 & 911.6 & 1017.5 & 1108.1 & 856.5 & 691.7 & 1185 \\
\hline $\begin{array}{l}\text { Disposable income } \\
\text { (PLN) }\end{array}$ & 735 & 761 & 835 & 929 & 1046 & 1114 & 1201 & 1235 & 1278 & 1299 & 1340 & 1386 & 1475 & 1598 \\
\hline $\begin{array}{l}\text { Average monthly } \\
\text { expenses per capita } \\
\text { (PLN) }\end{array}$ & 702 & 697 & 751 & 816 & 911 & 964 & 1005 & 1028 & 1059 & 1062 & 1079 & 1091 & 1132 & 1176 \\
\hline $\begin{array}{l}\text { Share of expenses in } \\
\text { disposable income } \\
(\%)\end{array}$ & 95.4 & 91.5 & 90.5 & 87.9 & 87.1 & 86.5 & 83.7 & 83.2 & 82.8 & 81.7 & 80.5 & 78.7 & 76.7 & 73.6 \\
\hline
\end{tabular}

Source: own compilation based on data from the Institute of Agricultural and Food Economics — National Research Institute in Warsaw and on the 2014 Agricultural Statistical Yearbook.

worldwide. The surplus of milk was the reason to develop exports of dairy products (Seremak-Bulge and Bodył, 2014). Export development became particularly intense after Poland's accession to the EU (Pietrzak and Szajner, 2006). Higher EUR/PLN exchange rates encouraged milk processors to export milk and dairy products. The exchange rate can be defined as the price of euro expressed in the national currency (PLN) (Samuelson and Nordhaus, 1996).

High purchase prices of milk encourage farmers to produce more milk. However, higher milk prices reduce consumer purchases.

In Poland, annual per capita consumption of milk and butter increased by over $25 \%$ and over $2 \%$, respectively, between 2004 and 2017. The sharpest increase in annual per capita consumption of milk and butter was recorded in 2016 (222 liters of milk and $4.7 \mathrm{~kg}$ of butter) (Table 2).

Changes in the structure of milk and dairy products consumption in Poland are caused by various factors such as population ageing, increased rates of female economic activity and growing consumer awareness. The consumption level of cheese and curd in Poland varies depending on economic and social characteristics of households. The highest consumption levels are recorded in farms where managing person has a university degree. The relatively high price of these product types (when compared to meat prices, for instance) means that the consumption of ripening cheese is lower in poorer households. Also, the place of residence has an impact on the consumption of these products, with city dwellers consuming more ripening cheese than rural residents.

In Poland, the consumption of yoghurt has grown intensively since 2000 , increasing by over $80 \%$ within 17 successive years. The increase in consumption of these products is driven by growing consumer interest in healthy lifestyles, and in having a diet based on products deemed "healthy" which are natural and rich in nutritional values. However, these products are also a source of calories due to high carbohydrate contents. 
Bórawski, P., Grzybowska-Brzezińska, M., Dunn, J. W. (2020). Dynamics of dairy products consumption in Poland against the background of the EU. J. Agribus. Rural Dev., 2(56), 145-154. http://dx.doi.org/10.17306/JJARD.2020.01296

Table 2. Milk and dairy products consumption in Poland in 2004-2017 and forecasts for 2018-2022

\begin{tabular}{|c|c|c|c|c|c|c|c|c|c|c|c|}
\hline \multirow[b]{2}{*}{ Year } & \multicolumn{2}{|c|}{$\begin{array}{c}\text { Consumption per } \\
\text { capita }\end{array}$} & \multicolumn{9}{|c|}{ Average monthly consumption in households (kg per capita) } \\
\hline & $\begin{array}{c}\text { milk } \\
(1)\end{array}$ & $\begin{array}{c}\text { butter } \\
(\mathrm{kg})\end{array}$ & $\begin{array}{c}\text { milk } \\
(1)\end{array}$ & $\begin{array}{l}\text { whole } \\
\text { milk } \\
(1)\end{array}$ & $\begin{array}{c}\text { milk (with less } \\
\text { than } 3.2 \% \text { fat } \\
\text { content) }\end{array}$ & $\begin{array}{l}\text { con- } \\
\text { densed } \\
\text { milk } \\
(\mathrm{kg})\end{array}$ & $\begin{array}{l}\text { yogurt } \\
\text { (kg) }\end{array}$ & $\begin{array}{c}\text { cheese } \\
(\mathrm{kg})\end{array}$ & $\begin{array}{c}\text { cottage } \\
\text { cheese } \\
(\mathrm{kg})\end{array}$ & $\begin{array}{c}\text { ripening } \\
\text { and processed } \\
\text { cheese } \\
(\mathrm{kg})\end{array}$ & $\begin{array}{c}\text { cream } \\
(\mathrm{kg})\end{array}$ \\
\hline 2004 & 174 & 4.4 & 4.59 & 2.45 & 2.14 & 0.04 & 0.35 & 0.87 & 0.53 & 0.34 & 0.44 \\
\hline 2005 & 173 & 4.2 & 4.43 & 2.45 & 1.98 & 0.04 & 0.34 & 0.87 & 0.52 & 0.35 & 0.43 \\
\hline 2006 & 176 & 4.3 & 4.12 & 2.31 & 1.81 & 0.04 & 0.37 & 0.89 & 0.52 & 0.36 & 0.41 \\
\hline 2007 & 179 & 4.2 & 3.84 & 2.19 & 1.65 & 0.05 & 0.40 & 0.89 & 0.52 & 0.37 & 0.40 \\
\hline 2008 & 182 & 4.3 & 3.64 & 2.13 & 1.51 & 0.05 & 0.44 & 0.88 & 0.51 & 0.37 & 0.40 \\
\hline 2009 & 187 & 4.7 & 3.64 & 2.02 & 1.49 & 0.05 & 0.47 & 0.92 & 0.52 & 0.40 & 0.40 \\
\hline 2010 & 189 & 4.3 & 3.51 & 2.14 & 1.37 & 0.06 & 0.54 & 0.94 & 0.55 & 0.39 & 0.38 \\
\hline 2011 & 194 & 4.0 & 3.42 & 2.08 & 1.34 & 0.05 & 0.54 & 0.95 & 0.56 & 0.39 & 0.37 \\
\hline 2012 & 193 & 4.1 & 3.39 & 2.04 & 1.35 & 0.05 & 0.52 & 0.94 & 0.55 & 0.39 & 0.37 \\
\hline 2013 & 206 & 4.1 & 3.35 & 2.08 & 1.27 & 0.02 & 0.51 & 0.83 & 0.44 & 0.38 & 0.37 \\
\hline 2014 & 205 & 4.2 & 3.25 & 1.99 & 1.26 & 0.02 & 0.50 & 0.82 & 0.43 & 0.39 & 0.36 \\
\hline 2015 & 213 & 4.5 & 3.16 & 1.93 & 1.23 & 0.02 & 0.50 & 0.83 & 0.43 & 0.40 & 0.35 \\
\hline 2016 & 222 & 4.7 & 3.08 & 1.98 & 1.10 & 0.02 & 0.53 & 0.85 & 0.44 & 0.41 & 0.36 \\
\hline 2017 & 218 & 4.5 & 2.99 & 1.93 & 1.06 & 0.02 & 0.52 & 0.86 & 0.44 & 0.42 & 0.36 \\
\hline \multicolumn{12}{|c|}{ Forecast } \\
\hline 2018 & 219.51 & 4.5 & 2.97 & 1.94 & 1.10 & 0.02 & 0.51 & 0.87 & 0.45 & 0.42 & 0.36 \\
\hline 2019 & 221.00 & 4.7 & 3.00 & 1.96 & 1.12 & 0.03 & 0.50 & 0.87 & 0.47 & 0.41 & 0.36 \\
\hline 2020 & 221.54 & 4.7 & 3.02 & 1.98 & 1.14 & 0.03 & 0.49 & 0.88 & 0.48 & 0.41 & 0.36 \\
\hline 2021 & 222.16 & 4.8 & 3.04 & 2.00 & 1.16 & 0.03 & 0.49 & 0.88 & 0.48 & 0.41 & 0.37 \\
\hline 2022 & 222.67 & 4.9 & 3.06 & 2.01 & 1.18 & 0.03 & 0.49 & 0.88 & 0.48 & 0.41 & 0.37 \\
\hline
\end{tabular}

Source: Rynek mleka 2005-2019.

In the analysis of milk and dairy products consumption in Poland, the consumption of products considered to be richer in nutritional values tends to follow an upward trend whereas a decrease is observed in the consumption of high-calorie products. When making a decision to buy a food product, the consumer is guided by many selection criteria. However, milk and dairy products may differ in role and importance from other food groups. The dairy market is affected by increasing competition, and the main goal of producers is to meet customer expectations and preferences and make their customers highly satisfied with product quality. Defining consumer quality criteria means searching for the most recent trends in consumer preferences underpinning their market choices. Polish consumers expect the products available on the market to be diverse, of a high quality, sensory attractive, with a high nutritional value, produced using natural methods and safe while requiring little effort and time to prepare for consumption (Grzybowska-Brzezińska and Grzywińska-Rąpca, 2016).

It is difficult to explain the changes in milk and dairy products consumption in Poland. It is widely confirmed 
that dairy products are nutrient-dense foods in the overall human diet, and they contain necessary nutrients such as calcium, potassium, protein, fat and vitamin D, which help to keep the human body healthy (Simo et al., 2016). Milk and dairy products "may reduce the risk of osteoporosis and cardiovascular diseases and type 2 diabetes, and are the best complement for a healthy meal" (Gulseven and Wohlgenant, 2017).

In their forecast, the authors of this paper expect the consumption of milk and dairy products in Poland to change. On one hand, the consumption of whole milk, milk with less than $3.2 \%$ fat content, cottage cheese, condensed milk and cream will increase. However, the consumption of yogurt and cheese will follow a downward trend (Table 2).

According to FAO data, global consumption of milk and dairy products will return to levels recorded 20 years ago (Bórawski and Kowalska, 2017). The average level of milk consumption around the world is $109 \mathrm{~kg} /$ person. Although the highest consumption occurs in North America, the levels recorded in China and the EU are increasing (Baer-Nawrocka et al., 2012). Milk consumption in the European Union, United States and Australia is almost three times the world average level (Bórawski and Kowalska, 2017). Milk shortages in Asian countries have increased despite an increase in production, while the shortage of dairy products in Africa has not changed (Seremak-Bulge and Bodył, 2014).

OECD data shows that in EU countries, average consumption of fresh dairy products decreased between 2004 and 2018 from $94.52 \mathrm{~kg}$ per capita to $88.17 \mathrm{~kg}$ per capita (a decline by $6.7 \%$ ). In turn, Eurostat data shows that in 2018 in the EU, butter consumption was at a level of $4.3 \mathrm{~kg}$ per capita, which is the same as in the previous two years (Rynek mleka, 2019).

In the future, the consumption of fluid milk will decline whereas the consumption of cheese and other processed dairy products will increase. In France, Germany and Spain, the consumption of flavored, vitaminenriched, lactose-free, and plant-based milk has been observed to follow an upward trend. Almost all EU countries have noticed an increase in organic milk production and consumption. Austria, for example, exports organic milk to Germany and Italy (EU-28, 2018).

Butter consumption in 2018 was $4.33 \mathrm{~kg}$ per capita, which is higher than in $2004(3.57 \mathrm{~kg})$. This increase is the effect of changes driven by consumers who consider butter to be a healthful product more natural than margarine. "Although EU-28 butter prices in September 2018 decreased by 19\% against September 2017's record-high of level of EUR 6,500 (USD 7,735) per ton, they were still five percent above the prices of Oceania or U.S.-origin butter" (EU-28, 2018).

A forecast was elaborated in order to evaluate the future changes in milk and dairy products consumption. It suggests that per capita consumption of fresh dairy products and casein will increase in 2009-2023. In turn, the consumption of butter, cheese, skim milk powder, whole milk powder and whey powder will decrease in the EU for numerous reasons. First, the consumption of lactose-free dairy products will follow an upward trend. Moreover, the overall EU population is going to stagnate and will decline in some countries.

In the analysis of milk and milk products consumption in EU countries, the consumption of products considered to be richer in nutritional values tends to follow an upward trend whereas a decrease is observed in the consumption of high-calorie products. Milk is one of the basic and most valuable food products in human diet, and therefore an increase in the consumption of skim milk is experienced.

Additionally, strong competition in the milk market will cause farmers from some EU countries to exit the business (Table 3 ).

Both in EU countries and around the world, milk is mostly consumed fresh or as only slightly processed products. According to forecasts, the share of fresh products in total consumption of dairy products will increase due to strong demand in developing countries (driven by an increase in incomes and population growth). However, in the EU, fresh products consumption will decrease in favor of processed products. OECD-FAO forecasts that EU milk production in 2019-2028 will grow at a slower rate than average global production growth. Production will increase through improved cow productivity (at an annual rate of $1.1 \%$ ) while cow numbers will decrease at an annual average rate of $0.5 \%$. In the European Union, the share of organic milk in the production mix will increase. Currently, in countries such as Austria, Sweden, Latvia, Greece and Denmark, over $10 \%$ of milk is produced organically. On average, around 3\% of EU milk production comes from organic farms.

Growth in world milk production is projected to increase by $22 \%$ over the projection period, with a large share of the increase coming from Pakistan and India. 
Bórawski, P., Grzybowska-Brzezińska, M., Dunn, J. W. (2020). Dynamics of dairy products consumption in Poland against the background of the EU. J. Agribus. Rural Dev., 2(56), 145-154. http://dx.doi.org/10.17306/JJARD.2020.01296

Table 3. Consumption of dairy products in the EU in 2004-2018 and forecasted levels for 2019-2023 (kg)

\begin{tabular}{|c|c|c|c|c|c|c|c|c|c|c|c|c|c|c|}
\hline \multirow{2}{*}{ Year } & \multicolumn{2}{|c|}{$\begin{array}{l}\text { Fresh dairy } \\
\text { products }\end{array}$} & \multicolumn{2}{|c|}{ Butter } & \multicolumn{2}{|c|}{ Cheese } & \multicolumn{2}{|c|}{$\begin{array}{l}\text { Skim milk } \\
\text { powder }\end{array}$} & \multicolumn{2}{|c|}{$\begin{array}{l}\text { Whole milk } \\
\text { powder }\end{array}$} & \multicolumn{2}{|c|}{ Whey powder } & \multicolumn{2}{|c|}{ Casein } \\
\hline & total & $\begin{array}{c}\text { per } \\
\text { capita }\end{array}$ & total & $\begin{array}{l}\text { per } \\
\text { capita }\end{array}$ & total & $\begin{array}{c}\text { per } \\
\text { capita }\end{array}$ & total & $\begin{array}{l}\text { per } \\
\text { capita }\end{array}$ & total & $\begin{array}{l}\text { per } \\
\text { capita }\end{array}$ & total & $\begin{array}{l}\text { per } \\
\text { capita }\end{array}$ & total & $\begin{array}{l}\text { per } \\
\text { capita }\end{array}$ \\
\hline 2004 & $46,657.39$ & 94.52 & $1,763.58$ & 3.57 & $8,161.33$ & 16.53 & 963.85 & 1.11 & 290.15 & 0.59 & $1,273.92$ & 0 & 113.43 & 0.23 \\
\hline 2005 & $47,248.1$ & 95.36 & $1,795.27$ & 3.62 & $8,511.17$ & 17.18 & 880.89 & 0.95 & 284.44 & 0.57 & $1,272.46$ & 0 & 116.75 & 0.24 \\
\hline 2006 & $47,140.71$ & 94.8 & $1,882.31$ & 3.79 & $8,726.15$ & 17.55 & 807.57 & 0.95 & 306.41 & 0.62 & $1,278.27$ & 0 & 114.6 & 0.23 \\
\hline 2007 & $46,635.18$ & 93.43 & $2,047.24$ & 4.10 & $8,680.79$ & 17.39 & 708.73 & 0.88 & 346.73 & 0.69 & $1,370.61$ & 0 & 131.91 & 0.26 \\
\hline 2008 & $46,367.57$ & 92.57 & $2,034.38$ & 4.06 & $8,634.81$ & 17.24 & 600.44 & 0.72 & 317.81 & 0.63 & $1,338.08$ & 0 & 125.03 & 0.25 \\
\hline 2009 & $46,263.8$ & 92.07 & $1,827.45$ & 3.64 & $8,680.42$ & 17.27 & 786.82 & 1.09 & 239.15 & 0.48 & $1,158.41$ & 0 & 90.21 & 0.18 \\
\hline 2010 & $46,608.24$ & 92.51 & $2,022.85$ & 4.01 & $8,754.25$ & 17.38 & 685.85 & 0.90 & 254.75 & 0.51 & $1,370.90$ & 0 & 113.02 & 0.22 \\
\hline 2011 & $46,343.36$ & 91.79 & $2,007.06$ & 3.98 & $8,792.72$ & 17.41 & 688.93 & 0.95 & 295.74 & 0.59 & $1,286.60$ & 0 & 105.36 & 0.21 \\
\hline 2012 & $46,108.43$ & 91.18 & $2,078.57$ & 4.11 & $8,913.79$ & 17.63 & 677.18 & 1.01 & 267.19 & 0.53 & $1,376.07$ & 0 & 88.31 & 0.17 \\
\hline 2013 & $46,112.74$ & 91.08 & $2,044.31$ & 4.04 & $8,655.05$ & 17.09 & 696.65 & 1.10 & 352.11 & 0.7 & $1,406.24$ & 0 & 94.91 & 0.19 \\
\hline 2014 & $45,670.57$ & 90.10 & $2,117.06$ & 4.18 & $8,869.62$ & 17.50 & 720.87 & 1.19 & 367.46 & 0.72 & $1,352.72$ & 0 & 92.89 & 0.18 \\
\hline 2015 & $45,898.73$ & 90.44 & $2,134.09$ & 4.21 & $9,200.72$ & 18.13 & 740.67 & 1.23 & 320.64 & 0.63 & $1,371.63$ & 0 & 89.26 & 0.18 \\
\hline 2016 & $45,119.94$ & 88.79 & $2,187.19$ & 4.30 & $9,358.52$ & 18.42 & 767.78 & 1.27 & 354.1 & 0.70 & $1,256.67$ & 0 & 71.27 & 0.14 \\
\hline 2017 & $45,030.23$ & 88.48 & $2,198.3$ & 4.32 & $9,472.09$ & 18.61 & 774.07 & 1.27 & 360.15 & 0.71 & $1,305.75$ & 0 & 69.88 & 0.14 \\
\hline 2018 & $44,939.08$ & 88.17 & $2,207.28$ & 4.33 & $9,687.25$ & 19.01 & 820.65 & 1.35 & 363.3 & 0.71 & $1,340.22$ & 0 & 71.16 & 0.14 \\
\hline \multicolumn{15}{|c|}{ Forecast } \\
\hline 2019 & $45,055.36$ & 88.62 & $2,177.16$ & 4.26 & $9,717.59$ & 19.01 & 808.31 & 1.28 & 339.61 & 0.66 & $1,308.66$ & 0 & 75.74 & 0.15 \\
\hline 2020 & $45,163.37$ & 88.28 & $2,157.00$ & 4.22 & $9,653.63$ & 18.85 & 800.94 & 1.25 & 313.50 & 0.62 & $1,311.56$ & 0 & 78.33 & 0.15 \\
\hline 2021 & $4,525.57$ & 88.46 & $2,139.21$ & 4.18 & $9,594.64$ & 18.70 & 795.89 & 1.23 & 315.20 & 0.63 & $1,313.67$ & 0 & 80.59 & 0.16 \\
\hline 2022 & $45,342.49$ & 88.62 & $2,123.52$ & 4.15 & $9,540.24$ & 18.57 & 792.43 & 1.21 & 315.09 & 0.63 & $1,315.22$ & 0 & 82.57 & 0.16 \\
\hline 2023 & $45,416.45$ & 99.78 & $2,109.68$ & 4.13 & $9,490.08$ & 18.46 & 790.07 & 1.20 & 315.00 & 0.63 & $1,316.85$ & 0 & 84.30 & 0.16 \\
\hline
\end{tabular}

Source: own elaboration based on OECD data, n.d.

In 2027 , these two countries are expected to jointly account for $32 \%$ of global milk production. Most of the additional production in these countries will be consumed domestically as fresh dairy products. Over the projection period, the European Union's share in global exports of dairy commodities is expected to increase from $27 \%$ to $29 \%$. As the 2017 butter bubble continues to deflate, nominal and real prices for butter will decrease over the projection period. With the exception of skim milk powder (SMP), dairy prices are expected to decrease in real terms (OECD-FAO..., 2018).
Next, the authors of this paper analyzed the consumption of butter and butteroil across EU countries in 2008-2017. The data presented above confirms the increase in butter and butteroil consumption in most EU countries between 2008 and 2017 (Table 3). This can be the effect of growing production of milk and dairy products and of changing consumer preferences for milk and processed dairy products. The new consumer base has challenged the industry to extend their product range (Zuba-Ciszewska, 2018). The demand for dairy products in emerging economies that cannot fulfill their 
Bórawski, P., Grzybowska-Brzezińska, M., Dunn, J. W. (2020). Dynamics of dairy products consumption in Poland against the background of the EU. J. Agribus. Rural Dev., 2(56), 145-154. http://dx.doi.org/10.17306/J.JARD.2020.01296

domestic needs created an increase in global dairy trade (von Keyserlingk et al., 2013).

The consumption of butter and butteroil decreased in 2008-2017 in Belgium, Estonia, Germany, Luxemburg, and Spain. France is a leader in the consumption of butter and fats with an average consumption of ca. $7.8 \mathrm{~kg} /$ person, which is more than twice the average level for the $28 \mathrm{EU}$ countries. The lowest consumption (only $0.4 \mathrm{~kg} /$ person) was recorded in Spain. Due to lack of relevant data, this study did not include Bulgaria, Greece, Malta, Portugal, Romania and Slovenia (Table 4).

Table 4. Butter and butteroil consumption in the EU in 2008-2017 (kilograms/person)

\begin{tabular}{|c|c|c|c|c|c|c|c|c|c|c|c|c|c|c|c|}
\hline \multirow{2}{*}{ Country/region } & \multirow{2}{*}{2008} & \multirow{2}{*}{2009} & \multirow{2}{*}{2010} & \multirow{2}{*}{2011} & \multirow{2}{*}{2012} & \multirow{2}{*}{2013} & \multirow{2}{*}{2014} & \multirow{2}{*}{2015} & \multirow{2}{*}{2016} & \multirow{2}{*}{2017} & \multicolumn{5}{|c|}{ Forecast } \\
\hline & & & & & & & & & & & 2018 & 2019 & 2020 & 2021 & 2022 \\
\hline EU 28 countries & 3.6 & 3.6 & 3.6 & 3.6 & 3.7 & 3.7 & 3.7 & 3.9 & 3.9 & 3.8 & 3.8 & 3.7 & 3.7 & 3.7 & 3.7 \\
\hline Austria & 4.9 & 4.9 & 5.1 & 5.0 & 5.0 & 5.3 & 5.3 & 4.9 & 5.3 & 5.5 & 5.1 & 5.1 & 5.1 & 5.1 & 5.1 \\
\hline Belgium & 2.4 & 2.4 & 2.4 & 2.4 & 2.5 & 2.3 & 2.3 & 2.3 & 2.3 & 2.2 & 2.3 & 2.3 & 2.3 & 2.3 & 2.3 \\
\hline Bulgaria & - & - & - & - & 0.8 & 0.9 & 0.9 & - & - & - & - & - & - & - & - \\
\hline Cyprus & 1.4 & 1.4 & 1.8 & 1.8 & 1.9 & 1.8 & 1.9 & 1.9 & 1.9 & 1.9 & 1.9 & 1.8 & 1.8 & 1.8 & 1.8 \\
\hline Croatia & 0.9 & 1.2 & 1.0 & 0.6 & 1.0 & 1.0 & 1.2 & 1.6 & 1.5 & 1.5 & 1.4 & 1.3 & 1.2 & 1.2 & 1.2 \\
\hline Czech Republic & 4.7 & 5.0 & 4.9 & 4.9 & 5.2 & 5.0 & 5.1 & 5.5 & 5.4 & 5.0 & 4.9 & 5.0 & 5.0 & 5.0 & 5.0 \\
\hline Denmark & 1.8 & 1.8 & 1.8 & 1.8 & 2.5 & 3.9 & 4.9 & 5.0 & 6.3 & 6.2 & 6.0 & 5.0 & 4.6 & 3.7 & 2.9 \\
\hline Estonia & 4.3 & 5.7 & 4.3 & 4.1 & 2.5 & 1.5 & 2.2 & 1.6 & 2.7 & 2.7 & 2.9 & 3.0 & 3.1 & 3.2 & 3.2 \\
\hline Finland & 2.7 & 3.1 & 3.4 & 4.1 & 4.5 & 3.7 & 3.2 & 3.3 & 3.3 & 3.4 & 3.5 & 3.4 & 3.4 & 3.4 & 3.4 \\
\hline France & 7.5 & 7.7 & 7.6 & 7.6 & 7.3 & 7.7 & 8.3 & 8.2 & 8.2 & 8.0 & 7.9 & 7.8 & 7.8 & 7.8 & 7.8 \\
\hline Germany & 6.2 & 5.8 & 5.7 & 6.3 & 6.2 & 5.8 & 5.7 & 6.1 & 6.1 & 5.9 & 5.9 & 6.0 & 6.0 & 6.0 & 6.0 \\
\hline Greece & - & 0.6 & 0.6 & 0.7 & - & - & - & - & - & - & - & - & - & - & - \\
\hline Hungary & 0.9 & 1.0 & 1.0 & 0.9 & 1.0 & 1.0 & 1.2 & 1.6 & 2.2 & 2.5 & 2.7 & 2.9 & 3.3 & 3.9 & 4.6 \\
\hline Ireland & 2.5 & 2.4 & 2.4 & 2.4 & 2.4 & 2.4 & 2.4 & 2.4 & 2.4 & 2.4 & 2.4 & 2.4 & 2.4 & 2.4 & 2.4 \\
\hline Italy & 2.4 & 2.5 & 2.3 & 2.3 & 2.3 & 2.4 & 2.3 & 2.5 & 2.6 & 2.6 & 2.5 & 2.5 & 2.5 & 2.4 & 2.4 \\
\hline Latvia & 2.6 & 2.6 & 2.5 & 2.8 & 2.8 & 2.3 & 2.9 & 3.0 & 2.9 & 3.5 & 3.0 & 3.0 & 2.9 & 2.9 & 2.9 \\
\hline Lithuania & 1.4 & 2.2 & 2.0 & 2.2 & 2.8 & 2.6 & 3.0 & 3.3 & 3.8 & 4.1 & 4.0 & 3.9 & 3.8 & 3.7 & 3.7 \\
\hline Luxemburg & - & - & 5.8 & 6.0 & 6.1 & 5.4 & 5.3 & 5.6 & 5.6 & 5.5 & 5.6 & 5.7 & 5.7 & 5.7 & 5.7 \\
\hline Malta & - & - & - & - & - & - & - & - & - & - & - & - & - & - & - \\
\hline Netherlands & 3.3 & 3.7 & 3.0 & 3.0 & 3.0 & 3.0 & 3.0 & 3.9 & 4.3 & 4.0 & 3.9 & 3.7 & 3.5 & 3.5 & 3.4 \\
\hline Poland & 4.3 & 4.4 & 4.2 & 4.2 & 3.9 & 4.0 & 4.1 & 4.3 & 4.6 & 4.5 & 4.5 & 4.4 & 4.3 & 4.3 & 4.3 \\
\hline Portugal & - & - & - & - & - & - & - & - & - & - & - & - & - & - & - \\
\hline Romania & - & 0.8 & 0.6 & 0.6 & - & - & - & - & - & - & - & - & - & - & - \\
\hline Slovakia & 2.2 & 2.8 & 2.6 & 2.6 & 3.2 & 3.0 & 3.2 & 3.6 & 3.9 & 3.9 & 3.8 & 3.7 & 3.6 & 3.6 & 3.5 \\
\hline Slovenia & - & - & - & - & - & - & - & - & - & - & - & - & - & - & - \\
\hline Spain & 0.5 & 0.5 & 0.5 & 0.5 & 0.6 & 0.5 & 0.5 & 0.4 & 0.4 & 0.3 & 0.3 & 0.4 & 0.4 & 0.4 & 0.4 \\
\hline Sweden & 1.6 & 1.8 & 1.6 & 2.6 & 3.0 & 2.2 & 2.3 & 2.5 & 2.5 & 2.4 & 2.4 & 2.2 & 2.2 & 2.2 & 2.2 \\
\hline United Kingdom & 2.8 & 3.0 & 3.2 & 3.1 & 3.4 & 3.2 & 2.9 & 3.1 & 2.7 & 2.7 & 2.9 & 2.9 & 3.0 & 3.0 & 3.0 \\
\hline
\end{tabular}

- Data not available.

Source: own calculations based on 2004-2018 monthly milk price data for EU countries (EC, n.d.). 
In most European Union countries, vegetable fat dominates fat consumption. The greatest dominance of vegetable fats over animal fats is found in food consumed by people living in Spain, Greece and Cyprus who have a Mediterranean diet with a high proportion of oils and olive oil. In turn, the smallest share of vegetable fats in total fat consumption occurs in the diet of the inhabitants of Belgium, Hungary, Poland, Germany, Austria, and Croatia.

On the one hand, most EU countries are self-sufficient in the production of animal fats (butter and raw animal fats), but they have a low production volume of vegetable fats relative to domestic consumption and therefore remain a significant importer. On the other hand, many European Union members produce insufficient volumes of butter and raw animal fats to address domestic consumption, which suggests they have a problem in their distribution policy and organization of the common market for vegetable and animal fats (Rosiak, 2016).

According to OECD-FAO forecasts, global milk production in 2019-2028 will grow at a rate of $1.7 \%$ per year, to 981 million tons in 2028. Countries with the largest increases in milk production include India and Pakistan, which will jointly be responsible for more than half of global production growth in the next decade. As a consequence, in 2028, these countries will account for over $30 \%$ of global production. The global volume of trade in skim milk powder will increase at an average annual rate of $1.7 \%$; the corresponding rates for butter and whole milk powder are $1.6 \%$ and $1.1 \%$, respectively.

This study analyzes the relationships between variables explaining milk production in Poland. The relationship is measured with the correlation coefficient which takes on values ranging between -1 and 1 . When the coefficient is 0 , it means there is no correlation between variables. A positive correlation coefficient means an increase in both features, while a negative increase means an increase in one feature and a decrease in the other (Bórawski, 2015).

Milk consumption was positively correlated with milk production, net trade in dairy products and average monthly expenses per capita (Table 5).

So far, this study has explored the determinants of dairy products consumption and their mutual correlations. However, it was also considered important to examine the impact of drivers of milk consumption in Poland using a regression equation (Table 6). The multiple regression routine found milk consumption in Poland to

Table 5. Results of correlation analysis between explanatory variables

\begin{tabular}{lcccccccccc}
\hline \multicolumn{1}{c}{ Specification } & $Y_{1}$ & $X_{1}$ & $X_{2}$ & $X_{3}$ & $X_{4}$ & $X_{5}$ & $X_{6}$ & $X_{7}$ & $X_{8}$ & $X_{9}$ \\
\hline$Y_{1}$ : milk consumption per capita & 1.000 & 0.905 & -0.829 & -0.778 & -0.828 & -0.030 & 0.809 & 0.088 & 0.973 & -0.921 \\
$X_{1}$ : milk production (thousand liters) & 0.905 & 1.000 & -0.987 & -0.961 & -0.986 & 0.106 & 0.795 & 0.179 & 0.895 & -0.714 \\
$X_{2}$ : PLN/EUR exchange rate & -0.829 & -0.987 & 1.000 & 0.986 & 0.999 & -0.152 & -0.740 & -0.203 & -0.819 & 0.597 \\
$X_{3}$ : milk prices paid to farmers in & -0.778 & -0.961 & 0.986 & 1.000 & 0.987 & -0.167 & -0.628 & -0.163 & -0.759 & 0.516 \\
$\begin{array}{l}\text { Poland (EUR/100 kg) } \\
X_{4} \text { : retail milk prices (PLN/liter) }\end{array}$ & -0.828 & -0.986 & 0.999 & 0.987 & 1.000 & -0.151 & -0.736 & -0.201 & -0.817 & 0.595 \\
$X_{5}$ : FAO global milk price index & -0.030 & 0.106 & -0.152 & -0.167 & -0.151 & 1.000 & 0.072 & -0.054 & -0.062 & 0.110 \\
$X_{6}$ : net trade in dairy products (EUR & 0.809 & 0.795 & -0.740 & -0.628 & -0.736 & 0.072 & 1.000 & 0.223 & 0.838 & -0.780 \\
million) & & & & & & & & & & \\
$X_{7}$ : disposable income (PLN) & 0.089 & 0.179 & -0.203 & -0.163 & -0.201 & -0.054 & 0.223 & 1.000 & 0.082 & -0.075 \\
$X_{8}$ : average monthly expenses per & 0.973 & 0.895 & -0.819 & -0.759 & -0.817 & -0.062 & 0.838 & 0.082 & 1.000 & -0.930 \\
capita (PLN) & & & & & & & & & & \\
$X_{9}$ : share of expenses in the dispos- & -0.921 & -0.714 & 0.597 & 0.516 & 0.595 & 0.110 & -0.799 & -0.075 & -0.930 & 1.000 \\
able income (\%) & & & & & & & & &
\end{tabular}

Source: own calculations. 
Bórawski, P., Grzybowska-Brzezińska, M., Dunn, J. W. (2020). Dynamics of dairy products consumption in Poland against the background of the EU. J. Agribus. Rural Dev., 2(56), 145-154. http://dx.doi.org/10.17306/J.JARD.2020.01296

Table 6. Results of regression analysis between the change in milk production in Poland (as the dependent variable) and independent variables

\begin{tabular}{lllll}
\hline \multicolumn{1}{c}{ Specification } & Coefficient & Std. error & $F$ test & $p$-value \\
\hline$X_{1}:$ milk production (thousand liters) & 2.75 & & & \\
$X_{2}:$ PLN/EUR exchange rate & 10.4 & & & \\
$X_{4}:$ retail milk prices (PLN/liter) & -8.3 & 53.125 & 190.759 & 0.000 \\
$X_{8}:$ average monthly expenses per capita (PLN) & 0.216 & & & \\
\hline
\end{tabular}

Source: own calculations.

be dependent on $X_{1}$ (milk production, thousand liters), $X_{2}$ (euro exchange rate) and $\mathrm{X}_{8}$ (average monthly expenses per capita, PLN). The regression coefficient of $X_{4}$ (retail price of milk, PLN/liter) was negative which means that an increase in milk prices makes consumption levels decrease. The $\mathrm{R}^{2}$ determination coefficient was high and reached 0.99 which means a good fit of the model.

\section{SUMMARY}

Milk and dairy products consumption has increased around the world, especially in China, India and the EU. In Polish self-employed households, milk and dairy products consumption has decreased over the last five years. However, the consumption of ripened and processed cheese was on the rise.

The consumption of milk and dairy products in Poland changed between 2004 and 2018. The biggest increase was observed in the consumption of yogurt $(+$ $48.6 \%)$, milk $(+34.9 \%)$, and ripened and processed cheese $(+23.5 \%)$. Conversely, the study period witnessed a decrease in the average monthly consumption of whole milk $(-21.2 \%)$, milk with a fat content less than $3.2 \%(-50.5 \%)$, concentrated milk $(-50.0 \%)$, cottage cheese $(-17.0 \%)$ and cream $(-18.8 \%)$.

At the EU-wide level, a decrease in the consumption of fresh dairy products and casein was observed, whereas the consumption of butter, cheese, skim milk powder, whole milk powder and whey powder increased over the study period. Such changes can result from the consumers shifting their preferences towards more processed foods. Another reason could be the changing lifestyle of modern consumers who often have lunch and dinner in restaurants instead of preparing home-cooked meals.
The analysis shows that milk consumption in Poland depended mainly on $X_{1}$ (milk production, thousand liters), $X_{2}$ (euro exchange rate) and $X_{8}$ (average monthly expenses per capita, PLN). Conversely, the increase in milk prices had a negative impact on consumption levels.

\section{SOURCE OF FINANCING}

This paper was funded under a project financed by the National Science Center (NCN) in Poland, 2018/29/B/ HS4/00392.

\section{REFERENCES}

Baer-Nawrocka, A., Grochowska, R., Kiryluk-Dryjska, E, Seremak-Bulge, J., Szajner, P. (2012). Światowy rynek mleka i jego wpływ na polskie mleczarstwo po zniesieniu kwot mlecznych [The global milk market and the impact on Polish dairy after the abolition of milk quotas]. Warszawa: IERiGŻ-PIB.

Bórawski, P. (2015). Tendencje w handlu zagranicznym polskiego sektora mleczarskiego [Trends in foreign trade of the Polish dairy sector]. Zesz. Nauk. SGGW Warsz. Probl. Roln. Świat., 15(30), 1, 7-20.

Bórawski, P. (2016). Integration and logistic activities based on dairy farms in Mazowsze and Podlasie regions. J. Agribus. Rural Dev., 3(41), 263-271.

Bórawski, P., Kowalska, M. (2017). Zmiany w produkcji i konsumpcji mleka i produktów mleczarskich w Polsce na tle UE [Changes in Production and Consumption of Milk and Dairy Products in Poland Compared with Other European Union Countries]. Zesz. Nauk. SGGW Warsz. Probl. Roln. Świat., 17(XXXII), 3, 17-28.

Bórawski, P., Pawlewicz, A., Parzonko, A., Harper, J. K., Holden, L. (2020). Factors Shaping Cow's Milk Production in the EU. Sustainability, 12, 420. 
Bórawski, P., Grzybowska-Brzezińska, M., Dunn, J. W. (2020). Dynamics of dairy products consumption in Poland against the background of the EU. J. Agribus. Rural Dev., 2(56), 145-154. http://dx.doi.org/10.17306/JJARD.2020.01296

Dairy Report (2018). For a better understanding of the dairy world. IFCN The Dairy Research Network.

EU-28 (2018). Dairy and products annual. Dairy production affected by drought in Northern and Eastern Europe.

FAO (2013). FAO Food and Agriculture Organization: Milk and Milk Products. Retrieved from: http://www.fao.org/ economic/est/est-commodities/dairy/milk-and-milk-products/en/

Grzybowska-Brzezińska, M., Grzywińska-Rąpca, M. (2016). Konsumpcja mleka i przetworów mlecznych w gospodarstwach domowych w latach 2004-2013. Stud. Prac. WNEiZ US, 120-131.

Gulseven, O., Wohlgenant, M. (2017). What are the factors affecting the consumers' milk choices? Agric. Econ. Czech, 63(6), 271-282.

Guth, M. (2017). Diversity of milk production determinants in EU macro-regions with the predominance of intensive and extensive production in 2011. J. Agribus. Rural Dev. 2(44), 329-336.

KE (Komisja Europejska) (n.d.). Milk market observatory. Retrieved from: https://ec.europa.eu/agriculture/marketobservatory/milk_pl

Kołoszyc, E. (2016). Światowy rynek mleka-wybrane zagadnienia [World dairy market-selected issues]. Prac. Nauk. UE Wroc., 450, 287-297.

Milk and milk products (2013). Retrieved Feb $1^{\text {st }} 2015$ from: http://www.fao.org/fileadmin/templates/est/COMM_ MARKETS_MONITORING/Dairy/Documents/November 2013.pdf

OECD-FAO Agricultural Outlook 2018-2027 (2018). Retrieved from: http://www.fao.org/documents/card/en/c/ I9166EN

Ogunyale, D.S., Mayorga, R.V. (2017). A Fuzzy Inference Systems Approach for Risk Evaluation of Dairy Products Manufacturing Systems. Int. J. Cont. Sys. Rob., 2. Retrieved from: http://www.iaras.org/iaras/journals/ijcsr

Pietrzak, M., Szajner, P. (2006). Przetwórstwo, handel i spożycie mleka i produktów mlecznych w Polsce w latach
2003-2005 oraz prognozowane kierunki zmian [Processing, trade and consumption of milk and dairy products in Poland in the years 2003-2005 and forecasted directions of changes]. Rocz. Nauk Roln. Ser. G, 93(1), 92-101.

Rosiak, E. (2016). Spożycie thuszczów w Polsce i Unii Europejskiej [Fat consumption in Poland and the European Union]. Zesz. Nauk. SGGW Warsz. Probl. Roln. Świat., 16(XXXI), 2, 279-288.

Rynek mleka - stan i perspektywy (2016). Warszawa: IERiGŻ-IB, ARR, MRiRW.

Sahdev, S.L. (2015). Dairy Export Potential of Indian Dairy Products in International Market. J. Agric. Eng. Food Tech., 2(3), 200-208.

Samuelson, P.A., Nordhaus, W.D. (1996). Ekonomia. Warszawa: Wyd. Nauk. PWN.

Seremak-Bulge, J., Bodył, M. (2014). Spożycie mleka w Polsce na tle innych krajów [Milk consumption in Poland in comparison to other countries]. Zagad. Ekon. Roln., 1, 146-158.

Simo, D., Mura, L., Buleca, J. (2016). Assessment of milk production competitiveness of the Slovak Republic within the EU-27 countries. Agric. Econ. Czech, 62(10), 482-492.

Sobczyk, M. (2005). Statystyka. Warszawa: Wyd. Nauk. PWN.

von Keyserlingk, M.A.G., Martin, M.P., Kebreab, E., Knowlton, K.F., Grant, R.J., Stephenson, M., Sniffen, C.J., Harner, J.P., Wright, A.D., Smith, S.I. (2013). Invited review: sustainability of the US dairy industry. J. Dairy Sci., 96, $5405-5425$

Wiley, A.S. (2011). Milk for "Growth": Global and Local Meanings of Milk Consumption in China, India, and the United States. Food Food., 19(1-2), 11-33.

Wiley, A.S., Madison, J. (2007). The Globalization of Cow's Milk Production and Consumption: Biocultural Perspectives. Ecol. Food Nut., 46(3-4), 281-312.

Zuba-Ciszewska, M. (2018). The role of dairy cooperatives in reducing waste of dairy products in the lubuskie voivodeship. J. Agribus. Rural Dev., 1(47), 97-105. 